University of Nebraska - Lincoln

DigitalCommons@University of Nebraska - Lincoln

Faculty Publications: Department of Teaching, Department of Teaching, Learning and Teacher Learning and Teacher Education

Education

$5-2020$

\title{
The downfall: listening to non-urban communities and their language ideologies
}

Jessica Sierk

Theresa Catalano

Follow this and additional works at: https://digitalcommons.unl.edu/teachlearnfacpub

Part of the Bilingual, Multilingual, and Multicultural Education Commons, Curriculum and Instruction Commons, and the Teacher Education and Professional Development Commons

This Article is brought to you for free and open access by the Department of Teaching, Learning and Teacher Education at DigitalCommons@University of Nebraska - Lincoln. It has been accepted for inclusion in Faculty Publications: Department of Teaching, Learning and Teacher Education by an authorized administrator of DigitalCommons@University of Nebraska - Lincoln. 


\title{
The downfall: Listening to non-urban communities and their language ideologies
}

\author{
Jessica Sierk ${ }^{1} \&$ Theresa Catalano $^{2}$ \\ 1 St. Lawrence University \\ 2 University of Nebraska-Lincoln \\ Corresponding author: Jessica Sierk jsierk@stlawu.edu St. Lawrence University, \\ 23 Romoda Drive, Atwood 20, Canton, NY 13617
}

\begin{abstract}
Increased mobility due to globalization and other geopolitical shifts has changed school demographics worldwide. In the Midwest, much of this new immigrant population is Spanishspeaking and in need of language support. Consequently, schools play an important role in responding to the New Latino Diaspora. In this paper, we describe how unconscious language ideologies inhibited social change that could improve conditions for new student populations in two non-urban high schools in Nebraska (Stockbridge and Springvale, pseudonyms). This critical discourse analysis draws on ethnographic data from a larger study, including participant observations and semi-structured interviews. Findings reveal language ideologies that use language to mask issues of race/ ethnicity that represent a positive "us" and negative "them." We conclude by suggesting ways in which schools can take responsibility for developing the linguistic and cultural practices and ways of knowing unique to new student populations, rather than using language as an excuse for continued inequity.
\end{abstract}

Published in Critical Inquiry in Language Studies 17:2 (2020), pp 121-142.

doi:10.1080/15427587.2019.1626237

Copyright (c) 2019 Taylor \& Francis Group, LLC. Used by permission. 


\section{Introduction}

“New Latino Diaspora” (NLD) describes the temporary and permanent settlement of increasing numbers of Latinos in areas that had not traditionally been home to Latinos (Murillo \& Villenas, 1997). The often rapid demographic change associated with NLD communities has frequently resulted in fast-changing and improvisational inter-ethnic interactions (Hamann, Wortham, \& Murillo, 2002). In the traditional Latino Diaspora, the majority of the Hispanic ${ }^{1}$ population was concentrated in metropolitan areas (McHugh, 1989). However, this is not always the case in the New Latino Diaspora. Hamann and Harklau (2015) attribute the growth of New Latino Diaspora in nonurban $^{2}$ areas to immigration and inmigration driven by industries like agriculture, construction and landscaping, assembly and manufacturing, and poultry and meat processing. The resulting demographic change in communities that are both non-urban and have a significant Hispanic student population thus merits our attention. Language and the interplay between language, identity, and race/ethnicity play a central role in these inter-ethnic interactions, particularly in nonurban communities.

In light of the United States' most recent political transition, this topic is even more important than it has been in the past. Before the 2016 presidential election, non-urban communities were largely ignored. However, voters in non-urban areas were integral to Trump's win, in part because of many of his attitudes and beliefs about immigrants. This past election highlighted a major divide in urban and non-urban politics (Badger, Bui, \& Pearce, 2016; Kurtzleben, 2016). Hence, it is important to take a closer look at the realities of non-urban schools with high newcomer and established immigrant populations, as they are a microcosm of the larger society within which such demographic changes are influencing our nation's reaction and resistance to its changing demographic profile. Under the Trump administration, new immigration policies, such as the separation of children and their parents at the border (Frontline, 2018), increased deportations (Burnett, 2018), and the continued criminalization of migrants (Catalano \& Musolff, 2019), have exacerbated stress and trauma in these communities.

In this paper, we analyze how language ideologies come into

play as two non-urban communities (Stockbridge and Springvale, 
pseudonyms) think about how to adapt to changing demographics and newcomer populations. Research questions that guided our study include the following:

1) What role does language play in participant beliefs about interactions between newcomer and extant populations?

2) How does language as used by participants reveal their beliefs about differences between newcomer and extant populations?

3) What role do participants believe language has in improving relations between newcomer and extant populations and creating a sense of community?

\section{Conceptual framework}

We drew on multiple overlapping and complementary theoretical frameworks in the writing of this paper: Critical Race Theory/ LangCrit, Social Identity Theory, and Linguistic Assimilation. Together, these frameworks provide a more complete lens with which to examine how race, identity, and language intersect. Due to the racialization of Hispanic students in the context of the United States, simply looking at linguistic assimilation, without consideration of race, would fail to acknowledge the nuanced nature of the oppression these students face. Furthermore, since this study focuses on the co-constructed nature of social hierarchies, the conceptual framework needs to take into account how people categorize, and effectively "Other," new-comers in their social environments.

\section{Critical Race Theory/LangCrit}

Given this study's focus on racialization and its societal and educational implications, we used Critical Race Theory (CRT) as part of the conceptual framework. CRT emerged from the field of Critical Legal Studies (CLS) but has gone on to be used in a variety of fields, including education, offering a "lens to understand the obvious, and more insidiously subtle ways that race operates" (Brown, 2014, p. 329).

Related to this paper's examination of linguistic diversity, Kubota and Lin (2006) assert, "English language teaching entails complex relations of power fueled by racialization" (p. 488). Furthermore, Lee (2015) connects CRT to the field of TESOL, stating, "Critical 
questioning of the equating of English with Whiteness can seem particularly threatening to those deeply invested (and with good intentions) in a field deep-rooted in historical legacies of the colonial project" (p. 81). Thus, used in this way, CRT uncovers and challenges the way linguistic oppression bolsters racism, and vice versa.

We also drew from LangCrit, an off-shoot of CRT, to explain how language was used as an excuse for inequity. According to Crump's (2014) critical framework LangCrit, the intersection of linguistic (i.e., subject-as-heard) and racial(ized) (i.e., subject-as-seen) identities is important when considering how individuals negotiate and perform their identities. She asserts, "Understandings of language, identity, and belonging need to be informed by a theoretical lens that resists masking issues of race behind issues of language" (p. 219). Thus, audible identity differences are used in conversations about race to decrease the risk of being seen as racist. In relation to our study, LangCrit is particularly helpful in explaining the way that language masks issues related to race/ethnicity in participant interviews about newcomers, but also the way that identities are formed, rejected or accepted based on the way students speak.

\section{Social Identity Theory}

In this study, we aim to understand two non-urban communities' responses to changing demographics and Hispanic newcomers. Social Identity Theory (Tajfel \& Turner, 1985), provides a particularly useful framework from which to view perceptions of newcomers and ways in which they are talked about by established community members, but it also provides a foundation from which we can begin to understand the psychological basis of intergroup discrimination. This theory posits that it is human nature to categorize people, putting ourselves and others into separate groups. In addition, it is common practice to compare other groups to our groups and develop a favorable bias toward the group (or groups) to which we belong, ultimately wishing our group/s to be distinct from and positively compared to other groups. van Dijk's (1997) principle of the "ideological square" builds on this theory, proposing that there are four possible ways (hence, the "square") in which we can position our own groups and others in discourse. We can align ourselves positively and the "Other" negatively (e.g., positive “us”, negative “them”), or we can align ourselves 
negatively, and the "Other" positively. Alternatively, we could align both ourselves and others negatively, or both ourselves and others positively. The goal of Social Identity Theory is to explicate the typical social and psychological processes which produce intergroup conflict (Tajfel \& Turner, 1985, p. 43). Hence, when examining discourse from the nonurban communities of focus, this theory aids significantly in explaining the origin of certain ideological squaring found in the data.

\section{Linguistic assimilation}

One of the designated assimilative tasks of schooling in the United States, related specifically to immigrant students, concerns students' acquisition of English. Ruiz (1984) discusses three 'orientations' to language planning (language-as-problem, language-as-right, and language-as-resource) that are important to consider when examining how linguistic assimilation is, or is not, occurring in schools. The language-as-problem orientation is at the heart of the transition-maintenance controversy. As Ruiz states, one of the most common arguments against maintenance programs is that "multilingualism leads ultimately to a lack of social cohesiveness" (p. 21). Therefore, when language-as-problem is the dominant orientation toward language planning, bilingual programming will likely take on a transitional ap-

proach. Spener (1988) discusses transitional bilingual education and how it has been used as a politically acceptable way "to take away the immigrant child's language and culture and replace them with some form more suited to the social roles he or she can be expected to occupy as an adult in the host society" (p. 147). Thus, while assimilative, this approach to second language teaching relegates English learners to "low-status, poorly compensated slots in the opportunity structure," as "students who are mainstreamed out of transitional bilingual programs may not be sufficiently prepared to participate and compete in English-only classrooms" (p. 149).

In contrast to language-as-problem, the language-as-resource orientation views minoritized language communities as important sources of expertise. Ricento (2005) points out that the language-asresource orientation is often carried out in a way that is more consistent with language-as-commodity. "The employment of such discourses tends to perpetuate a view of language as instrument (as opposed to language as identity marker), and, by doing so, seeks to 
garner support for the teaching and learning of heritage languages by de-linking language from ethnicity or race" (p. 357). This is especially evident in the contrast between how language learning is conceived for students acquiring English versus how it is envisioned in world language departments, the former generally adhering to the language-as-problem orientation.

Generally, language is used as a metric and symbol of how well a particular group is assimilating. Valdés (2001) asserts, difficulties in learning English experienced by youngsters in school to their community's lack of commitment to becoming American" (p. 18). Border Studies researcher Bejarano (2005) discusses the impact English-only policies and xenophobic attitudes can have on immigrant youth stating, "These messages reach the ears of Mexican-descent youths, who then internalize these policies, inevitably feeling as though they do not belong in the United States. The language policy frames bilingualism as a liability, a socioeconomic noose promising to strangle youth" (p. 34). Taken together, Valdés and Bejarano illustrate the role language plays in students' experiences with assimilation in schools. Both difficulties in language learning and attempts to maintain one's native language may be seen as acts of resistance to assimilation.

Related to this phenomenon, Valenzuela (1999) found that "within the immigrant population, youth tend to subdivide further according to recency of arrival" (p. 181). Matute-Bianchi (1986) contrasted Mexican-oriented and MexicanAmerican students. The former are bilingual, enrolled in general or remedial classes, and participated in activities like the Sociedad Bilingue or soccer. The latter were described by school personnel as totally assimilated, preferring to speak English, and participating in "mainstream" school clubs. Similarly, Romo (1984) contrasted Mexicanos with Chicanos. Both groups distinguished themselves according to language use and legal status, among other variables. To be Chicano meant that one spoke English and was in the United States "legally." Rosaldo (1993) explains the relationship between citizenship and assimilation stating, "Full citizenship and cultural visibility appear to be inversely related. When one increases, the other decreases. Full citizens lack culture, and those most culturally endowed lack full citizenship" (p. 198). Adding language to this equation one could also say that full citizenship and linguistic visibility also tend to be inversely related. 
Crucially, all the main empirical studies referenced in this section come from California, Texas, and the 'traditional' Latino Diaspora (i.e., parts of the United States that have long hosted Latin American-descent populations as well as new arrivals). While these findings pertain to the present study, it is worth remembering that school responsiveness to the Hispanic student populations examined in this paper were more improvisational and less wellinformed than in the sites referenced in this section.

\section{Method}

\section{Participants}

Student participants were recruited from the entire population of general education students in the 12th grade at both Stockbridge and Springvale high schools. School personnel (e.g., teachers, guidance counselors, and administrators) who regularly interacted with student participants were also recruited to participate.

All participants were given pseudonyms to protect their anonymity. While the larger study was comprised of data collected from 21 students and 31 school personnel, we will concentrate on data from the participants described in Table 1 , whose interviews contained comments that represented language issues and ideologies, which are the focus of this paper.

\section{Data collection}

Twenty-seven days were spent doing participant observations (Spradley, 1980) during spring 2015 (14 at Springvale and 13 at Stockbridge), for a total of about $102 \mathrm{hr}$ of observation. These observations took place on various days of the week and in different settings (e.g., Stockbridge's "grand march" before prom, assemblies, school hallways, homeroom periods, and classrooms). Students were observed in 40 different classes (23 at Springvale and 17 at Stockbridge), representing a variety of subject areas, both core and elective. Ethnographic interviews (Spradley, 1979) were conducted with all 52 participants during April and May 2015. These interviews were audio-recorded and later transcribed. Follow-up interviews were conducted on a voluntary 
Table 1. Research participants.

\begin{tabular}{lll} 
Pseudonym & Site & Description \\
\hline Alexis & Springvale & White student who attended Springvale K-12 \\
Mrs. Armstrong & Springvale & White music teacher \\
Ms. Artz & Stockbridge & White family and consumer science teacher \\
Ms. Brodie & Springvale & White business teacher \\
Chloe & Springvale & White student who attended Springvale K-12 \\
Daniel & Stockbridge & Vietnamese student who attended Stockbridge K-12 \\
Eddie & Springvale & Guatemalan student who attended Springvale 5-12 \\
Mrs. Falk & Springvale & White mathematics teacher \\
Mr. Hughes & Stockbridge & White guidance counselor \\
Javier & Springvale & Mexican student who attended Springvale K-12 \\
Mrs. Logan & Springvale & White family and consumer science teacher \\
Mr. Morris & Stockbridge & White social studies teacher \\
Tiffany & Springvale & White student who attended Springvale K-12 \\
Mr. Vaughn & Springvale & White industrial technology teacher \\
Mr. Vogel & Springvale & White social studies teacher \\
\hline
\end{tabular}

basis with the 13 student participants (ten from Springvale, three from Stockbridge) in October and November 2015.

\section{Data analysis}

This paper stems from a larger ethnographic research project (Sierk, 2016) that examined how students made sense of their own identities in relation to that of their community, as they transitioned from K-12 education to their postsecondary lives. In the original study, a large number of comments from interviews related to language issues and ideologies emerged. As such, we gathered data by doing a lexical search of the original data file of all interviews for any wording or issues that related to language. We then collated these data into a new data file that was uploaded into MAXQDA (1989-2017), and thematic coding was conducted producing the following three major themes: language as an excuse, ideological squaring, and language variety versus a melting pot. Below, we tabulate each theme in Table 2 and provide the number of tokens and a salient example from each.

Once themes were determined (from in-vivo coding), we gathered and analyzed salient examples from each using tools from critical discourse studies (CDS). CDS is a "problem oriented interdisciplinary research movement" (Fairclough, Mulderrig, \& Wodak, 2011, p. 357), 
Table 2. Language-related themes and tokens.

\begin{tabular}{lll} 
Theme & Tokens & Example \\
\hline Language as an Excuse & 20 & $\begin{array}{l}\text {... and they don't speak English and so no one } \\
\text { like can talk to them. }\end{array}$ \\
Ideological Squaring & 48 & $\begin{array}{l}\text { We have a generation who just speaks Spanish } \\
\text { still so for them to relate to us that just speak } \\
\text { English is hard }\end{array}$ \\
$\begin{array}{l}\text { Language Variety vs. } \\
\text { Melting Pot }\end{array}$ & $\begin{array}{l}\text {.. . she taught it differently than from what } \\
\text { they actually spoke.... we are really a melt- } \\
\text { ing pot of all different cultures and all different } \\
\text { languages ... }\end{array}$ \\
\hline
\end{tabular}

which emphasizes "the way in which language is implicated in issues such as power and ideology that determine how language is used, what effect it has, and how it reflects, serves, and furthers the interests, positions, perspectives, and values of, those who are in power" (Waugh, Catalano, Al Masaeed, Hong, \& Renigar, 2015, p. 72). CDS scholars critically analyze discourse n, 2001, p. 140), and

\section{Findings}

\section{"They don't speak English and so no one like can talk to them": language as an excuse}

We found 20 examples in the data where alleged lack of ability to speak English by newcomer students was upheld as a reason for why newcomers and the extant student population did not "mix" (note that there were eight tokens of "mix" found in the data that related to this issue). Although many of the participants felt that this was problematic, and expressed a desire for students from different backgrounds to spend more time together in school and out, the blame for this segregation was put largely on language issues, as in the following example:

So like they come to school and they think they own the place and they don't speak English and so no one like can talk to them. ${ }^{3}[\ldots]$ I don't even know but [Eddie] came here and he wanted to like conform, he wanted to learn English, he wanted to like get into sports, and they're just like no you have to learn our language and we're just like 
this is America, like yeah there's different languages, but learn English, like we're an English-speaking school yeah. (Chloe, white Springvale student, Follow-up interview, October 12, 2015)

Chloe's example demonstrates theoretical rationalization, a type of legitimization or justification of the speaker's reasoning in which the reasons for the argument are presented as "because that's the way things are," but they "invariably embody moral values (and social prejudices) which are detached from the moral logic from which they stem ... and presented as commonsense fact" (van Leeuwen \& Wodak, 1999, p. 107). In this justification for lack of interaction with newcomer students in the community, Chloe has positioned "us" against "them," but only "they" are responsible for compromising and making an effort to fit in. There is no mention of the possibility that the extant monolingual community could also make an effort to learn Spanish, and thus aid in communication efforts so all parties would feel comfortable. Hence, in the recontextualization of the situation, Chloe has deleted effort and volition on the part of local townspeople (van Leeuwen \& Wodak, 1999), using "this is America" as a "that's the way things are" matter of fact reasoning intended to justify the blame being only on one side.

In addition, Eddie (who came from Guatemala in elementary school) is held as an example of the "model immigrant" (Bucholtz, 2004) who learned English, and had a desire to play sports. He "wanted to conform" and thus has had success integrating with the extant student population. What Chloe neglected to mention is that Eddie also came much earlier, and hence has had more time to acquire the language. Below, Mrs. Armstrong, a white Springvale teacher, attributes lack of participation by later arriving students (e.g., students that come during the high school years instead of elementary school) to "struggling" with language:

The activities and stuff in the school have changed a lot because the Hispanic kids do not typically do a lot of the extracurricular activities um the kids that have been here for a long time like we have a lot of kids that go from kindergarten all the way through those kids do they get involved and do things. Kids that come in later um and especially 


\section{if they're struggling with language they don't do choir} and speech and football and wrestling. They don't do all of those things. (Mrs. Armstrong, Personnel interview, May 6,2015 )

As in Chloe's comment, Mrs. Armstrong does not acknowledge that there might be something the community could do to attract more newcomers to their extra-curricular programs, like for example, offer sports that many of these students are passionate about and have experience with, such as soccer, or provide education to parents (in Spanish) so they understand the cultural codes involved in playing sports or being in choir in their new community. All of these examples (and others in the data not mentioned here) provide ample support for Unger Palmer's (2003, p. 128) study, which found that extraand co-curricular activities were organized and delivered in such a way that "Latina immigrants were systematically excluded from participating." Faculty and staff in Unger Palmer's study assumed that students lacked the language skills, sports training, transportation or other support necessary to participate in after-school events and sports. In contrast, Latina participants revealed that lack of participation stemmed more from students or parents not knowing where to go to ask for accurate information or assistance, and no cultural interpreters to "decipher the school culture," and a mistrust between families and schools due to this lack of cultural understanding. According to Unger Palmer (2003, p. 127) the most “completely disempowering component of the schooling experience of Hispanic immigrant students" was "the community's participation in developing students' academic and cultural resources."

We also found that many members of the community laid the blame for lack of participation and overall school success on the Hispanic students and their families, largely through their lack of English proficiency. Instead of looking to what the community could do (such as provide cultural liaisons to help decode school practices and build trust), and to address life circumstances and needs of the students, language was a convenient mask or proxy for issues of race and fear of the "Other" (Crump, 2014).

One final point regarding Mrs. Armstrong's comment is the metonymy "the Hispanic kids," which lumps a very diverse group together (students born in the U.S., students that have recently migrated from 
Mexico or Guatemala, students that speak very different languages or are bi/multilingual). This comment excludes students like Eddie, who identify as Hispanic, but do participate in extra-curriculars. There are two possible explanations for this. First, it is possible that Mrs. Armstrong sees Eddie as an anomaly because she does not know other students like him. Second, because he speaks English well, has been in Springvale a relatively long time, and participates in extra-curriculars, Mrs. Armstrong does not think of Eddie as "Hispanic" and thus "Hispanic" for Mrs. Armstrong, could index students that do not know English and are more recent arrivals. Below, Mrs. Falk, a white Springvale teacher, again rationalizes the problem in terms of Spanish-speaking students not learning English, using the adverb "still" as in "just speaks Spanish still" to reference the moral value and concept of "this is America," which was expressed by Chloe earlier:

Um I think we're still a small town atmosphere where most people know everyone. Um obviously more diverse um which is kind of a struggle because we have a generation who just speaks Spanish still so for them to relate to us that just speak English is hard. (Mrs. Falk, Personnel interview, May 11, 2015)

In the above example which blames the "struggle" for the extant monolingual population and newcomers to interact on lack of English, the adverb "still" is a subtle moral evaluation that implies that a long time has passed, and that this generation of Spanish-speakers should have learned English by now. Mrs. Falk's statement demonstrates a common myth that language can be learned very quickly, and that Spanish-speakers do not want to learn English.

Most of the examples featured in the data that try to explain segregation between "Hispanics" and the extant White population were from students and school personnel who were not Hispanic. However, Eddie (mentioned by Chloe as a model of conformity and example of "what TO do" in terms of how to integrate into the community), explains how his situation was different than the way many of the current newcomer students experience school. That is, unlike his current classmates, when Eddie first came to Springvale, there were only a few students needing English support, so he was placed in the classroom with his classmates right away. He then explains 
why the school now puts students that are learning English in one classroom together:

I think the school did that because they thought they were helping them get along with each other and all of them help each other out with their English instead of mixing them with us when they could've learned so much faster. Because when I came it wasn't that big ESL was just like 6 or 7 of us and we were all in different grades so then I actually did have to talk to my classmates and have try to communicate and yeah I was mixed with all my classmates so that's how we became um I mean more of a family I guess. But as of them, I think they're all in the same level or grade they're just within each other and they're not being mixed with us where we could socialize together. (Eddie, Guatemalan Springvale student, Follow-up interview, November 9, 2015)

Eddie's example provides another rationale for the segregation in the community. He believes that if the new students can be together with Englishspeaking students, this would improve interaction and eventual integration of immigrant students into the community as opposed to keeping them completely isolated in school with no opportunities to interact with their classmates. By referring to his classmates as "family," he shows his affection and comfort with classmates, something he wishes the newer arriving students could achieve.

While Eddie's point regarding opportunities for interaction with the extant student population during school is valid, it is also important to recognize that he does not mention alternative possibilities, such as dual language education. In a dual language program, students would have the opportunity to "mix," but also gain literacy and cultural skills in both languages, which would benefit the whole community. Most likely he does not mention this because he is not aware of this possibility and the advantages it could bring. In the final example from this theme, Daniel, a Vietnamese Stockbridge student, provides another explanation for lack of involvement (and in his case, academic achievement):

My grandpa was in the hospital for like 2 weeks straight and he doesn't speak any uh English so I had to be there right 
after school until like $4 \mathrm{AM}$ in the morning and repeat that the next day so it was pretty hard uh my grades kind of suffered. (Daniel, Student interview, April 23, 2015)

Daniel's example points to responsibilities that many immigrant students have, and the way they often serve as "language brokers" for their families (Faulstich Orellana, 2009). In Daniel's case, he must translate for his grandfather because the local health-care system does not have sufficient bilingual staff (despite the fact that a large part of the local population is now bilingual). Instead of blaming students' lack of English for not participating in school activities and events, school personnel would do well to consider how they might accommodate students' responsibilities outside of class by establishing "flexible schedules so that students could accommodate work demands and family roles as well as school" (Ginorio \& Huston, 2001, p. 17). In addition, if students were allowed access to dual language programs in which they could develop their academic knowledge of Spanish or Vietnamese (or other languages present in these two communities) and graduate with the Seal of Biliteracy documenting their bilingualism and biliteracy, these students could take jobs in local businesses and hospitals. This would mean students like Daniel would no longer need to have primary responsibility for translating for their families and teachers, freeing them up to spend more time on "their stuff," which Mr. Vaughn, a white Springvale teacher, and other faculty noted they felt bad about since the bilingual students were frequently asked to translate.

\section{“Everybody's really helpful”: ideological squaring}

Although there were many comments in the data in which participants pointed out how welcoming the community was, and how much they appreciated having classmates that brought in different cultural perspectives and languages, as seen from the previous examples, much of the data signified the opposite through subtle linguistic features which were not easily noticed at first. Deixis ${ }^{4}$ was particularly effective in positioning participants in relation to the newcomer youth, as seen in the following example: 
It's interesting at times especially with our Hispanic population some of them struggle with the English comprehension and even speaking English especially....

In this first part of the example, it is noteworthy that Mr. Vaughn refers to the students as "our" Hispanic population. The use of "our" is inclusive, and shows ownership for the students as part of the school community, hence positioning Hispanic students with himself and the school. However, in the rest of the example, the students' emerging knowledge of English is highlighted as a deficit, reinforced by the frequent use of the pronoun "them," which groups all of these students together, much like Mrs. Armstrong's comment (even though they may be from very different countries and speak very different varieties of Spanish or other indigenous languages):

... you know this year is ... probably a big change for this year that I didn't mention think normally we get about 3 or 4 new students a year, this year I think they said we're up to 14 , all Hispanics and probably out of the 14 I think 12 are very little to no English speaking ability so that's interesting especially being industrial tech because they usually try getting them out into regular classrooms and then you know rather than sticking them in a English class or a math class, they usually try and put them in a class where maybe they can do something so it somedays it's challenging trying to figure out something they can do. (Mr. Vaughn, white Springvale teacher, Personnel interview, May 6, 2015)

Above, Mr. Vaughn conveys another common myth that classes like industrial technology or drawing do not require English skills, and therefore, students should be put in those classes first (falling behind in subjects like Math or English/ Language Arts). On the contrary, Catalano (2016) found that if supports were not given in classes such as drawing, or industrial technology, students still had trouble understanding the teacher. In addition, his statement that "it's challenging trying to figure out something they can do" ignores funds of knowledge (González, Moll, \& Amanti, 2006) that students bring with them, even if they do not know English well, they come with many things 
that they do know, that could be drawn upon in their learning. Additionally, Mr. Vaughn's comment "rather than sticking them in an English class or a math class, they usually try and put them in a class ... " illustrates the metaphor HISPANICS ARE (STICKY) OBJECTS which brings to light his conceptualization of the students as adhesives or objects that can be placed where you want them, rather than human beings that have some volition and should have a voice in their own learning experiences.

According to Lakoff and Johnson (1980, p. 3), our conceptual system plays a central role in defining our everyday realities, and most of our conceptual system is metaphorical in nature. This means that we frame the way we think and what we do through metaphorical thought (Lakoff \& Johnson, 1980, p. 5). Metaphors, in which we compare two things that are alike in one particular way (in this case, we are comparing Hispanic students to objects) provide a window into the way we conceive of our world. Even though we are not often conscious of the metaphors we use, they still control our thought and structure what we perceive, how we get around in the world, and how we relate to people and they often provide evidence for the way we think about people, actions, and events (Lakoff \& Johnson, 1980, p. 5).

In the next example, the word “downfall” uncovers Ms. Brodie's negative attitude toward the newcomer students:

Um well like I said everybody's really helpful so if there's anything you ever need people will just go around the community and you can ask I guess basically ... um, I would say you know if you were just coming here, I would say about 3/4 of our population doesn't speak English so that's going to be kind of the downfall. (Ms. Brodie, white Springvale teacher, Personnel interview, May 6, 2015)

This example demonstrates Ms. Brodie's fear that the community is in a downward spiral, due largely to a population that "doesn't speak English." First, she presents a positive "us" (Tajfel \& Turner, 1985) by mentioning how "immigrant newcomers. She then indexes the Spanish-speaking population and associates it with the "downfall" of the town. "Downfall" is a metonymy that implies that lack of English will lead to the demise of Springvale. Metonymy is a figure of language and thought in which one entity is used to refer to another 
it is somehow related to (Littlemore, 2015, p. 4). Often, metonymies motivate the creation of powerful metaphors that reflect our conceptual system and can also be used to persuade others to agree with us. The word "downfall" originates from a type of trap that was used as a falling weight to kill or injure prey. So "downfall," which notes the direction and action of the weight, came to represent the object that fell down on an animal. Later, the meaning broadened to include anything that fell down and/or hurt or ruined someone/something, and even broader, to mean ruin in general. The example is also problematic in the sense that despite the fact that Ms. Brodie acknowledges that three-fourths of the current population (transformed by immigration) speaks Spanish, it does not occur to her that it would be useful to learn Spanish. Although several participants did mention in interviews that they would like to learn Spanish, these were students, and not teachers, and there seems to be little consideration of language learning on the part of the teachers and community at large in terms of part of the solution.

The ideology expressed in Ms. Brodie's statement is exactly the type of rhetoric that Donald Trump catered to in his political campaign in which he made immigration a central issue. It is our opinion that it is this type of discourse that needs attention in the form of counterstorytelling (LadsonBillings, 2013) and education in order for social justice to happen for students at Springvale, Stockbridge, and in similar situations. In addition, it is exactly by ignoring the voices such as Ms. Brodie's that right-wing candidates such as Donald Trump gain ground. Since right-wing populists claim to "represent THE people, in the sense of a homogenised ideal based on nativist ideologies" (Wodak, 2015, p. 21), listening to discourse such as that of Ms. Brodie and echoing their fears is an effective strategy to gain popular support, and this is one reason Trump was so successful in his campaign (Klinkner, 2017).

Metaphor/metonymy found in the data communicated much about the perception of school personnel and students about newcomers. Other metaphors that demonstrate ideological squaring include ESL STUDENTS ARE A HARMFUL SUBSTANCE (e.g., "Their class got a lot more exposure to ESL students."- Alexis, white Springvale student, Follow-up interview, October 23, 2015), HISPANICS ARE SHINY NEW TOYS (e.g., "You know I remember when we got our first Hispanic when I was in high school"- Mr. Morris, white Stockbridge teacher, 
Personnel interview, May 15, 2015), and finally, LANGUAGE IS A BAD HABIT (e.g., "They still are really in that habit of like their dialect like their own language” - Mrs. Logan, white Springvale teacher, Personnel interview, May 11, 2015).

In the case of the Alexis's comment, she mentions the word "exposure" three times in her interview, all relating to interactions that she thinks should be more common between the extant student population and newcomer students learning English. Performing a simple www.google.com search or looking the word up in an online dictionary reveals that although there are multiple meanings for the word "exposure"- none of them are positive and they include references to dangerous chemicals or asbestos, too much light (as in camera exposure), too much cold, or others. Hence, this subtle (but over-used) word by Alexis reveals her unconscious thinking about newcomer students in her town.

Mr. Morris's example of "when we got our first Hispanic," demonstrates how the participant frames the students in terms of a novel toy or item that he collects, something exotic, and of interest, but again, not something one might normally say about people. In the next example from Ms. Logan, when she says that students get in the "habit" of their "own language or dialect," she reveals much about the way she (as a monolingual English speaker) conceives of language use. Referring to it as a "habit" calls to mind other habits people have (such as smoking or biting their nails) in which they exhibit control over and can take steps to stop. However, this metaphor is problematic, because language does not function the way nail-biting or other bad habits do. And, the framing of language as a "habit," rather than a linguistic and cultural practice is problematic because it allows us to put the blame on the person who has the habit for continuing to practice it. As most people who speak more than one language know, speaking a language is deeply emotional, and connected to one's identity. It is not something one can merely change, or stop. Until one has learned another language well enough to express oneself on the same level they can in the first language, it is not an option to merely discontinue speaking and change to another. Moreover, just because someone knows another language does not mean they should stop speaking their other language. In many cases, doing so can be detrimental, and cause many problems related to identity and mental health, which can lead to problems in school. 
This relates back to Ricento's (2005) discussion of language as instrument, as opposed to language as identity marker.

This final example of the ideological square in terms of positive "us" and negative "them" is expressed by Mr. Vogel, a white Springvale teacher, in regard to the changing student population. During the 2014-2015 school year, Springvale High School's population of English learners increased by 118.75\% (Nebraska Department of Education, 2015). Most of this increase was due to the arrival of new students from Guatemala who spoke little to no English. In the example below, Mr. Vogel blends the qualities of WATER onto the recent Guatemalan newcomer students:

It depends on if that influx keeps coming the way that it is now and um it I think eventually that number will taper off um but um it's a whole different you know it's a whole different group of people it's a whole different uh language barrier to deal with and it's and then trying to understand a whole different culture to try to understand here everybody just assumes well they're the same and they're not um and so that's going to be that'll be something to deal with too and that's kind of what I was alluding to I think that's going to be something that they'll have to figure out you know how if this influx continues to happen. (Mr. Vogel, white Springvale teacher, Personnel interview, May 14, 2015)

Referring to large numbers of new migrants as an "influx" is common in immigration discourse (Catalano, 2017), but nevertheless, using words that we often employ to describe inflows of water into a lake or sea, is problematic. The reason is, when there is too much water (in this case, the water is the migrant population) it does not stop itself. It must be stopped before it causes damage. Therefore, in this frame, a logical conclusion is that someone must stop the water (e.g., immigrants from coming), thus triggering a policy response, but also playing upon the fears of the extant White population that is affected by the newcomers. According to Musolff (2016) metaphorical MOVEMENT scenarios in which water rushes into a container (e.g., the NATION, or in this case, Springvale) are easy for people to take for granted as just the way we talk about the topic. Metaphor scenarios are uses of metaphor in the media, and in public discourse in general 
that are repeated over time. As they are picked up by new speakers, they convey the speaker's interpretations of preceding utterances of the same metaphor over time as well as their own opinion they are invited to share. Metaphor scenarios (such as MOVEMENT OF MIGRANTS $\rightarrow$ MOVEMENT OF WATER) frame discourses in a way that includes "specific narrative and evaluative perspectives" and makes them "attractive for drawing strong inferences in political discourse as well as in policy planning” (Musolff, 2016, p. 30). In the case of immigration, WATER metaphors have been noted to be a primary rhetorical device in arguing for strong anti-immigration policies (Reynolds, 2015; Santa Ana, 2002), and the scenarios of too much water (e.g., immigrants coming in), and the need to stop it, are picked up by people who listen to the news, political campaigns, and everyday discourse. The danger in this metaphor use lies not only in the implications for voting for immigration policy (e.g., if you feel the migrants in your community represent an "influx," you will most likely vote for policies that limit it), but more importantly, these ideologies about newcomer students (who are a large part of the migrants moving to communities like Stockbridge and Springvale) will interfere with the ability to teach these students in an equitable manner, since this metaphor reveals thinking that views them as a threat.

\section{Language variety vs. melting pot: "she taught it differently than what they actually spoke"}

Many comments in the data indicated a general awareness by participants of the different language varieties spoken by students lumped into the category of "Hispanic." Below, Eddie points out language differences among Guatemalans:

So we still spoke our native language and dialects and everything, but when the few of us that did speak Spanish, our Spanish was fluent or perfect, instead of like the ones who are more towards the middle they didn't speak a native language, they spoke Spanish, but their Spanish had a different accent and different so yeah. (Eddie, Guatemalan Springvale student, Follow-up interview, November 9, 2015) 
In this comment, Eddie recognizes Guatemala's multilingual population, and the differences in Spanish proficiency depending on language contact and geographic location. Although Alexis is not from Guatemala like Eddie, she also has an awareness that not all Guatemalan students speak Spanish, and some are multilingual and speak various indigenous languages as well as Spanish:

But like in the elementary side like when she got a student who was from Guatemala but was from a specific tribe in Guatemala that had its own dialect so it wasn't Spanish but he could understand Spanish but it was another specific dialect like super, super rare type thing. (Alexis, white Springvale student, Follow-up interview, October 23, 2015)

In the next example, Tiffany notes that the Spanish that is spoken by Spanish teachers in her school does not often reflect the Spanish spoken by students in the community:

I heard that like what our Spanish teacher at Springvale like she taught it differently than from what they actually spoke so that's what made like some of the Hispanics mad at the school was yeah because that's why they didn't want to take Spanish because of how she taught it was different. (Tiffany, white Springvale student, Follow-up interview, October 12, 2015)

Below, Ms. Artz recognizes the transnational nature of students and language issues upon return to their country of origin, and how the way we sound when we speak (i.e., subject-as-heard) can influence identity construction as well as whether or not we are accepted by others (Crump, 2014):

I've had some Hispanic students that they have been here long enough that they hate going to Mexico because they get made fun of because they don't have the right accent and they don't speak Spanish well enough. (Ms. Artz, white Stockbridge teacher, Personnel interview, May 15, 2015) 
What all these examples have in common is that despite the fact that there is so much language variety among the newcomer students, as well as cultural and other types of variety (such as time they have spent in Stockbridge or Springvale, economic status, and knowledge of English), faculty and students tend to talk about them in terms of a homogenous "Hispanic student" label. In addition, although there appears to be a keen sense of awareness of language variety, nothing seems to be proposed or actually done to accommodate this variety. For example, no one proposes dual language programs which feature the teaching and valuing of local varieties along with the standard, and no one mentions the possibility of Spanish classes in general that are aligned with the needs of heritage speakers. In the case of the class Tiffany refers to as making "Hispanics mad," most likely those students dropped out of Spanish class or did not develop their academic Spanish because the Spanish courses were not relevant to their lives as Spanish speakers, or they did not meet the needs of heritage speakers which vary greatly from those in world language classes, thus leading to language loss. This language loss then causes problems such as those mentioned by Ms. Artz when students return to countries of origin, or when they try to speak with newcomer students. This furthers the division because of the students' discomfort and shame regarding their own Spanish attrition (due largely to the school's lack of any kind of home language support or development) and creates divides between more recent immigrants and students that come much earlier. This phenomenon is dealt with in depth by Mendoza-Denton (2008) who illustrates the newcomer and more established student divide in her study of Latina gang members in Los Angeles, as well as by Zúñiga and Hamann (2006, 2009) in their research about the impact of U.S.-Mexico transnationalism on students' schooling experiences.

Throughout the data, the overarching theme that English is the panacea for all students, and that learning English is the key to success, represents an ever-present myth harkening back to past times when the idea of the country being a "melting pot," in which everyone loses their own language and culture in the process of becoming American, was more widely supported than now. Mr. Hughes captures this idea nicely, "The thing I like about the school district is that we are really a melting pot of all different cultures and all different languages" (Mr. Hughes, white Stockbridge guidance counselor, interview, May 
15, 2015). According to Mr. Hughes and others, the key to fitting in is English, and if you do not know English, you do not know anything, as shown below:

Like [Eddie] he came from Guatemala and now he's like he's very very fluent in English, but when he came here he was like ... he didn't know anything and he just like ... now he's like he knows how to speak English fluently, he's like he gets a whole bunch of like scholarships and stuff, and he was really good at wrestling. I think they should be able to communicate with us ... with Hispanics. (Javier, Mexican Springvale student, Student interview, May 5, 2015)

In the comment above, Javier, who is a second-generation bilingual student with Mexican heritage, speaks about Guatemalan newcomers, comparing Eddie to the new students and reiterating the primacy of English and its importance in the success of newcomers. His use of the metonymy "anything" in "he didn't know anything" is particularly interesting, because in this PART FOR WHOLE metonymy, "anything" stands for "anything in English" - that is, his knowledge of English stands for any knowledge. Clearly, Eddie knew lots of things when he came, but in this metonymy, his funds of knowledge and anything else he brought to the table have been erased by the dominant ideology relating to English. What is also interesting is the way that second-generation and more established Hispanic students in the study also reproduce these same ideologies, even though at one time they, or their parents, spoke another (or more than one) language(s). Furthermore, not many people would argue that the newcomer students should not learn English; however, in the "melting pot" ideology, they should learn English but also lose their home languages, or at least never receive any further support to develop them academically. The very real notion that one can learn another language and still be able to speak their home language(s) was not found in the data. This is most likely due to the fact that the Hispanic students in the study have been around English-only ideologies for so long, they have forgotten or had never had the chance to learn about alternative options or ways of thinking about language that include multilingual perspectives. 


\section{Conclusion}

In this paper, we have discussed three ways that students and school personnel at Stockbridge and Springvale high schools perpetuated linguistic discrimination in their New Latino Diaspora settings. By using language as an excuse, students and school personnel placed the onus for a solution on the newcomers, setting themselves up as "powerless" to take action to rectify what some of them even acknowledged as unjust. Through the act of ideological squaring, students and school personnel illustrated Brown's (2014) point about the "more insidiously subtle ways that race operates" (p. 329). While students and school personnel relied on two sides of the ideological square (e.g., positive "us," negative "them"), there are still two other sides, which include positive "us," positive "them." Although language varieties were acknowledged, in relying on the melting pot myth, school personnel ignored both the subject-as-heard and the subject-asseen components of their students' identities (Crump, 2014) by lumping all Spanish speakers into one monolithic category that ignored, rather than built on the linguistic diversity present within their school. This all goes to show that without explicit attention, oppressive policies and practices will continue to rule our schools. In order to disrupt these policies, we must begin to view language not only as a resource and a right, but as activism.

Rather than focusing on a narrow, English-only approach to academic success for immigrant students that has been proven not to work time and time again, we must begin to engage students like Alexis, Tiffany, and Eddie in community action, guiding them as they become cultural interpreters tasked with helping their newcomer peers "decipher the school culture" (Unger Palmer, 2003, p. 127). We must promote dual language programs over subtractive instructional methods (Valenzuela, 1999), not only with emergent bi/multilingual students but also with established community members outside of the school in the way of language exchanges that bring parents from all linguistic communities in the area together.

While it is natural to categorize people, these types of community-based approaches may challenge the impulses about which Social Identity Theory posits, instead promoting a sense of belonging between groups so that they no longer need their group to be distinct from and perceived as innately better than other groups. Perhaps most 
importantly, we must have honest conversations about the way school personnel perceive their students and the ideologies they bring to school, as these can have a profound influence on how welcome students feel, as well as how well they learn in school. Zooming out to the broader picture, we must do a better job of listening to non-urban communities and providing them with alternative ways of thinking (e.g., dual language programs) if we are to truly "make America great again."

\section{Notes}

1. We recognize the complex nature of the debate between using "Hispanic" versus "Latin@/Latinx"; however, as a result of this study's students exclusively using the term "Hispanic" in their self-identifications, we have opted to remain consistent with their terminology throughout this paper.

2. We use the term "non-urban" throughout the paper to encompass both the rural and micropolitan nature of this study's two research sites. The term "micropolitan" corresponds with the United States Census Bureau's designation of an urban cluster (i.e., a place with a population between 10,000 and 50,000).

3. In excerpts from participant interviews, words or phrases in bold signify they are points of focus in the analysis.

4. "Deixis" refers to words used for purposes of positioning subjects in time and space such as"they" "them" "here" "there" "now".

Acknowledgments - A shorter version of this paper was presented as part of a panel on "Language as Activism" at the American Anthropological Association (AAA) Annual Meeting, Washington, D.C., December 1, 2017. The authors would like to thank the panel members, discussants, chair, and audience members for their comments and suggestions.

\section{References}

Badger, E., Bui, Q., \& Pearce, A. (2016, November. 11). The election highlighted a growing non-urban-urban split. New York Times. Retrieved from https://www. nytimes.com/2016/11/12/upshot/this-election-highlighted-a-growing-nonurban-urban-split.html

Bejarano, C. L. (2005). ¿Qué onda? Urban youth culture and border identity. Tucson: The University of Arizona Press.

Brown, K. D. (2014). Teaching in color: A critical race theory in education analysis of the literature on preservice teachers of color and teacher education in the US. Race Ethnicity and Education, 17(3), 326-345. doi:10.1080/13613324.2013. 832921 
Bucholtz, M. (2004). Styles and stereotypes: The linguistic negotiation of identity among Laotian American youth. Pragmatics, 14(2/3), 127-147. doi:10.1075/ prag.14.2-3.02buc

Burnett, J. (2018, January. 23). Trump's ICE deportations are up from Obama's figures, data show. NPR National. Retrieved from https://www.npr.org/2018/01/23/579884642/ trumps-ice-deportations-increase-from-obamas-figures-data-show

Catalano, T. (2016). New perspectives in language and education: Book 48. Talking about global migration: implications for language teaching. Bristol, UK: Multilingual Matters. doi:10.21832/9781783095551

Catalano, T. (2017). When children are water: Representation of Central American migrant children in public discourse and implications for educators. Journal of Latinos and Education., 16(2), 124-142. doi:10.1080/15348431.2016.1205988

Catalano, T., \& Musolff, A. (2019). 'Taking the Shackles off': Metaphor and metonymy of migrant children and border officials in the U.S. Metaphorik.De., 29, 11-46.

Crump, A. (2014). Introducing LangCrit: Critical language and race theory. Critical Inquiry in Language Studies, 11(3), 207-224. doi:10.1080/15427587.20 14.936243

Fairclough, N., Mulderrig, J., \& Wodak, R. (2011). Critical discourse analysis. In T. A. van Dijk (Ed.), Discourse studies (pp. 357-378). Thousand Oaks, CA: Sage.

Faulstich Orellana, M. (2009). Translating childhoods. New Brunswick, NJ: Rutgers University Press.

Frontline. (2018, July 31). Separated: Children at the border. Retrieved from https://www.pbs. org/video/separated-children-at-the-border-abt8su/

Ginorio, A., \& Huston, M. (2001). Si, Se Puede! Yes, we can: Latinas in school. Newton, IA: American Association of University Women Educational Foundation. Retrieved from https://history.aauw.org/files/2013/01/SiSePuede. pdf

González, N., Moll, L. C., \& Amanti, C. (Eds.). (2006). Funds of knowledge: Theorizing practices in households, communities, and classrooms. New York, NY: Routledge.

Hamann, E. T., Wortham, S., \& Murillo, E. G., Jr. (2002). Education and policy in the new Latino diaspora. In S. Wortham, E. G. Murillo Jr., \& E. T. Hamann (Eds.), Education in the new Latino diaspora: Policy and the politics of identity (pp. 1-16). Westport, CT: Ablex Publishing.

Hamann, E. T., \& Harklau, L. (2015). Revisiting education in the New Latino Diaspora. In E. T. Hamann, S. Wortham, \& E. G. Murillo Jr. (Eds.), Revisiting education in the New Latino Diaspora (pp. 3-25). Charlotte, NC: Information Age Publishing, Inc.

Klinkner, P. (2017). Commentary: Anti-immigrant views helped Trump win. Will they also cause his undoing? Chicago Tribune. Retrieved from http://www. chicagotribune.com/news/opinion/commentary/ct-trump-supporters-antiimmigrant-20170418-story.html. 
Kubota, R., \& Lin, A. (2006). Race and TESOL: Introduction to concepts and theories. TESOL Quarterly, 4O(3), 471-493. doi:10.2307/40264540

Kurtzleben, D. (2016, November. 14). Non-urban voters played a big part in helping Trump defeat Clinton. NPR Politics. Retrieved from http://www.npr.org/2016/11/14/501737150/ non-urban-voters-played-a-big-part-in-helping-trump-defeat-clinton

Ladson-Billings, G. (2013). Critical race theory - What it is not! In M. Lynn \& A. D. Dixson (Eds.), Handbook of critical race theory in education (pp. 34-47). New York, NY: Routledge.

Lakoff, G, \& Johnson, M. (1980). Metaphors we live by. Chicago, IL: University of Chicago Press.

Lee, E. (2015). Doing culture, doing race: Everyday discourses of 'culture' and 'cultural difference' in the English as a second language classroom. Journal of Multilingual and Multicultural Development, 36(1), 80-93. doi:10.1080/014346 32.2014 .892503

Littlemore, J. (2015). Metonymy: hidden shortcuts in language, thought and communication. Cambridge: Cambridge University Press. doi:10.1017/ CBO9781107338814

Matute-Bianchi, M. E. (1986). Ethnic identities and patterns of school success and failure among Mexican-descent and Japanese-American students in a California high school: An ethnographic analysis. American Journal of Education, 95(1), 233-255. doi:10.1086/444298

McHugh, K. E. (1989). Hispanic migration and population redistribution in the United States. Professional Geographer, 41(4), 429-439. doi:10.1111/j.0033-0124.1989.00429.x

Mendoza-Denton, N. (2008). Homegirls: Language and cultural practice among Latina youth gangs. Malden, MA: Blackwell Publishing. doi:10.1002/9780470693728

Murillo, E., \& Villenas, S. (1997). East of Aztlin: Typologies of Resistance in North Carolina Communities. Paper presented at 1st annual conference of Reclaiming Voices: Ethnographic Inquiry and Qualitative Research in a Postmodern Age, Los Angeles, CA.

Musolff, A. (2016). Political metaphor analysis: Discourse and scenarios. New York, NY: Bloomsbury Publishing.

Nebraska Department of Education. (2015). 2014-2015 state of the schools report: A report on nebraska public schools. Retrieved from http://reportcard. education.ne.gov/

Reynolds, C. (2015). "Illegal children": Metaphors and terminology used in newspaper coverage of central American minors during summer 2014 (doctoral dissertation). The University of Arizona, Tucson.

Ricento, T. (2005). Problems with the 'language-as-resource' discourse in the promotion of heritage languages in the U.S.A. Journal of Sociolinguistics, 9(3), 348-368. doi:10.1111/ j.1360-6441.2005.00296.x 
Romo, H. (1984). The Mexican origin population's differing perceptions of their children's schooling. Social Science Quarterly, 65(2), 635-650.

Rosaldo, R. (1993). Culture \& truth: The remaking of social analysis. Boston, MA: Beacon Press. Ruiz, R. (1984). Orientations in language planning. Journal of the National Association for Bilingual Education, 8(2), 15-34. doi:10.1080/0885507 2.1984.10668464

Santa Ana, O. (2002). Brown tide rising: Metaphors of Latinos in contemporary American public discourse. Austin: University of Texas Press.

Scollon, R. (2001). Action and text: Towards an integrated understanding of the place of text in social (inter)action, mediated discourse analysis and the problem of social action. In R. Wodak \& M. Meyer (Eds.), Methods of critical discourse analysis (1st ed., pp. 139-183). London, UK: Sage.

Sierk, J. L. (2016). Coming of age in the New Latino Diaspora: An ethnographic study of high school seniors in Nebraska (doctoral dissertation). University of Nebraska, Lincoln.

Spener, D. (1988). Transitional bilingual education and the socialization of immigrants. Harvard Educational Review, 58(2), 133-153. doi:10.17763/ haer.58.2.x7543241r7w14446 Spradley, J. P. (1979). The Ethnographic Interview. Belmont, CA: Wadsworth.

Spradley, J. P. (1980). Participant Observation. New York, NY: Holt, Rinehart and Winston. Tajfel, H., \& Turner, J. C. (1985). The social identity theory of intergroup behavior. In W. W. G. Austin (Ed.), Psychology of intergroup relations (2nd ed., pp. 7-24). Chicago, IL: Nelson-Hall.

Unger Palmer, M. T. (2003). The schooling experience of Latina immigrant high school students (doctoral dissertation). University of North Carolina at Chapel Hill, North Carolina.

Valdés, G. (2001). Learning and not learning English: Latino students in American schools. New York, NY: Teachers College Press.

Valenzuela, A. (1999). Subtractive schooling: U.S.-Mexican youth and the politics of caring. Albany: State University of New York Press.

van Dijk, T. A. (1997). What is political discourse analysis? Belgian Journal of Linguistics, 11 (1), 11-52. doi:10.1075/bjl.11.o3dij van Leeuwen, T., \& Wodak, R. (1999). Legitimizing immigration control: A discourse-historical analysis. Discourse Studies, 1(1), 83-118. doi:10.1177/1461445699001001005

Waugh, L. R., Catalano, T., Al Masaeed, K., Hong, D. T., \& Renigar, P. (2015). Critical discourse analysis: History, approaches, relation to pragmatics, critique, trends and new directions. In A. Capone. \& J. Mey (Eds.), Interdisciplinary studies in pragmatics, culture and society (pp. 71-136). Berlin, Germany: Springer Verlag.

Wodak, R. (2015). The politics of fear: what right-wing populist discourses mean. Thousand Oaks, CA: SAGE Publications. doi:10.4135/9781446270073

Zúñiga, V., \& Hamann, E. T. (2006). Going home? Schooling in Mexico of transnational children. CONfines De Relaciones Internacionales Y Ciencia Política, 2(4), 41-57. 
Zúñiga, V., \& Hamann, E. T. (2009). Sojourners in Mexico with U.S. school experience: A new taxonomy for transnational students. Comparative Education Review, 53(3), 329-353. doi:10.1086/599356 